\title{
THE PHANTOM HOLOCAUST
}




\title{
Jewish Cultures of the World
}

Edited by Matti Bunzl, University of Illinois, Urbana-Champaign, and Jeffrey Shandler, Rutgers University

Published in association with the Allen and Joan Bildner Center for the Study of Jewish Life, Rutgers University

\author{
Advisory Board \\ Yoram Bilu, Hebrew University \\ Jonathan Boyarin, University of North Carolina
}

Virginia R. Dominguez, University of Illinois, Urbana-Champaign

Susannah Heschel, Dartmouth College

Barbara Kirshenblatt-Gimblett, New York University

Jack Kugelmass, University of Florida

Riv-Ellen Prell, University of Minnesota

Aron Rodrigue, Stanford University

Mark Slobin, Wesleyan University

Yael Zerubavel, Rutgers University 


\section{THE PHANTOM HOLOCAUST}

Soviet Cinema and Jewish Catastrophe

OLGA GERSHENSON

RUTGeRS UNIVERSITY PRES S

New Brunswick, New Jersey, and London 
Library of Congress Cataloging-in-Publication Data

Gershenson, Olga.

The phantom Holocaust : Soviet cinema and Jewish catastrophe / Olga Gershenson.

p. cm. - (Jewish cultures of the world)

Includes bibliographical references and index.

ISBN 978-0-8I35-6I8I-3 (hardcover : alk. paper) - ISBN 978-0-8I35-6I80-6 (pbk. : alk. paper) - ISBN 978-0-8135-6182-0 (e-book)

I. Holocaust, Jewish (1939-1945), in motion pictures. 2. Jews in motion pictures.

3. Motion pictures-Soviet Union. 4. Motion picture industry-Soviet Union. I. Title. PNi995.9.H $53 \mathrm{G}_{44} 2013$

791.43'658405318—dc23

2012041969

A British Cataloging-in-Publication record for this book is available from the British Library.

Copyright (C) 2013 by Olga Gershenson

All rights reserved

No part of this book may be reproduced or utilized in any form or by any means, electronic or mechanical, or by any information storage and retrieval system, without written permission from the publisher. Please contact Rutgers University Press, I06 Somerset Street, New Brunswick, NJ 0890I. The only exception to this prohibition is "fair use" as defined by U.S. copyright law.

Visit our website: http:/ / rutgerspress.rutgers.edu

Manufactured in the United States of America 
To the memory of my grandparents 
